\title{
FERTILITY RATE USING THE PALMORE FORMULA IN EAST JAVA PROVINCE: A STUDY OF 2015 SUPAS
}

\author{
Muhammad Abdul Khafidz Maftukh ${ }^{1}$, Lutfi Agus Salim² ${ }^{2}$ Farizah Mohd Hairi ${ }^{3}$ \\ 1,2,3 Faculty of Public Health, Universitas Airlangga, 60115 Surabaya, East Java, Indonesia \\ ${ }^{3}$ Department of Social and Preventive Medicine, Faculty of Medicine, University of Malaya, Kuala Lumpur, Malaysia \\ Corresponding Author: Muhammad Abdul Khafidz Maftukh \\ E-mail: khafidz310@gmail.com
}

\begin{abstract}
Fertility is an important indicator for the success of state development, especially in the health sector. It can be estimated through direct and indirect methods. This study aimed to determine the fertility rate in East Java province indirectly using the Palmore Formula. This study was a descriptive analysis using secondary data from the 2015 Inter-census Population Survey / Survei Penduduk Antar Sensus (SUPAS). It calculated the rate directly and manually. The Total Fertility Rate (TFR) was at 2.02 per two children born by each mother in East Java province. It was compared with the national average published by the Central Bureau of Statistics within 5 periods of SP1990, SUPAS 1995, SP2000, SUPAS 2005, and SP2010. In each period, the rate was lower without any difference. The Palmore Formula is considered a good method for estimating fertility rates.
\end{abstract}

Keywords: fertility, Palmore formula, infant mortality rate, child woman ratio.

\begin{abstract}
ABSTRAK
Fertilitas merupakan indikator tolak ukur keberhasilan pembangunan negara khususnya pada bidang kesehatan. Fertilitas dapat dihitung secara langsung dan cara tidak langsung. Penelitian ini bertujuan untuk mengetahui angka fertilitas Provinsi Jawa Timur dengan menggunakan metode tidak langsung yaitu metode Palmore Formula. Penelitian ini merupakan penelitian analisis deskriptif dengan menggunakan data sekunder dari data Survei Penduduk Antar Sensus (SUPAS) 2015. Perhitungan TFR dilakukan secara manual dan tidak langsung. Angka TFR sebesar 2,02 per dua anak yang dilahirkan setiap ibu di Provinsi Jawa Timur. Angka tersebut dibandingkan dengan angka nasional yang dipublikasi oleh Badan Pusat Statistik (BPS) dalam waktu 5 periode dari SP1990, SUPAS 1995, SP2000, SUPAS 2005, dan SP2010. Angka tersebut tidak mengalami penurunan pada setiap periode tanpa ada perbedaan. Palmore Formula cukup bagus dalam menghasilkan angka estimasi fertilitas.
\end{abstract}

Kata kunci: fertilitas, metode Palmore, tingkat kematian bayi, rasio anak ibu.

\section{INTRODUCTION}

Fertility is an important indicator for population to measure the success of a country's development, especially in the health sector. The fertility rate determines the population growth rate in addition to mortality and migration to a particular area. High fertility rates indicate a high population growth rate; it will lead to high population density in the future. The density of a population affects the development and economy in a region too. The government program must ensure the health and well-being of their people is taken care off. One of the benchmarks for a person's wellbeing can be seen in the Total Fertility Rate (TFR). The rate could be used as the data source for calculating future population growth directly or indirectly, and thus it is necessary to control the fertility rate to avoid overgrowth of the population.

Direct fertility calculations are rarely conducted in Indonesia because because of incomprehensive data. Birth registration data are not completely available due to lack of awareness of birth reporting at the beginning of the year (Salim, 2018). With complete birth data, the Age-Specific Fertility Rate (ASFR) can be more accurate for direct calculation. For now, the TFR is possibly estimated using indirect methods.

The Central Bureau of Statistics mentioned four common estimation methods, namely the Palmore, Rele, Biological, and GunasekaranPalmore methods. Each estimation method has its advantages and disadvantages. One of the advantages is providing easier calculation with 
predetermined indicators and easier data collection for TFR estimation, especially in areas that have inadequate administrative processes.

The method of estimating the TFR in each region is different as the quality and availability of the data between regions are also different. Thus, the most complete and valid data e.g., Riskesdas, IDHS, SP, SUSENAS, Inter-census Population Survey (SUPAS), etc., are adjusted. Various regions have implemented TFR estimation methods according to the criteria of each region. This study chose to use the Palmore method that can estimate the TFR in East Java province according to the 2015 Inter-census Population Survey. According to the Central Bureau of Statistics, Palmore compiled three formulas, namely formula A, B, and C. Formula A that has been updated is a more efficient indirect calculation method (Wahyuni, 2012). Compared to other methods, the Palmore method uses quite a lot of indicators. The Palmore method used an indicator of infant mortality to calculate fertility. This study calculated the total fertility rates in East Java province using the Palmore method on the 2015 Inter-census Population Survey.

\section{METHODS}

In order to obtain the data and to analyse efficiently and systematically, this study used a descriptive research design. Descriptions and interpretations on natural phenomena as well as man-made phenomena were retrieved. Direct treatment or control of variables did not test hypotheses as would have been done in experimental research. This study was a cross-sectional design using the Palmore Formula A to calculate the TFR from 2015 Inter-census Population Survey.

The population was the overall population in East Java regions. The samples were the total sampling of the population. The data were live birth children, married women, live children, women of childbearing age, and population of East Java province according to age group and gender. The 2015 Inter-census Population Survey data were published by the East Java Provincial Central Bureau of Statistics.

Research variables included the TFR and estimation methods. The TFR was calculated from the available sources. This study referred to the calculation of the statistical data source using Microsoft Excel.

\section{RESULTS}

The Palmore Formula A was used to calculate the TFR. The Palmore Formula A assessed the following aspects:

$$
\begin{aligned}
\text { TFR }= & 12.0405+13.5277 \text { IMR }+11.1042 \\
& \text { CWR }-176.4889 \mathrm{CP}-6.4698 \text { PEM } \\
\text { TFR }= & \text { Total birth rate per 1,000 women } \\
\text { IMR }= & \text { Infant mortality rate per 1,000 live } \\
& \text { births } \\
\text { CWR = } & \text { Ratio of children } 0-4 \text { years per } 1,000 \\
& \text { women aged } 15-49 \text { years } \\
\mathrm{CP}= & \text { Percentage of children aged less than } \\
& 5 \text { years } \\
\text { NS } \quad & \text { Percentage of married women aged } \\
& 20-24 \text { years }
\end{aligned}
$$

According to the formula, the TFR was calculated using several indicators, namely Infant Mortality Rate (IMR), Child Woman Rate (CWR), number of children aged 0-4 years, and number of married women aged 2024 years.

\section{Infant Mortality Rate (IMR)}

IMR calculation was done in Mortpak app (Informer Technologies, 2020) using 2015 Inter-census Population Survey of East Java Province. Initial data consisted of Child Born

Table 1. Total ALH and AMH in East Java Province in 2015

\begin{tabular}{ccccc}
\hline Female Age Group & ALH & AMH & RALH & RAMH \\
\hline $15-19$ & 171,297 & 170,820 & 0.118236893 & 0.117907647 \\
$20-24$ & 868,495 & 862,034 & 0.597382096 & 0.592937988 \\
$25-29$ & $1,688,121$ & 165,8344 & 1.153925972 & 1.133571712 \\
$30-34$ & $2,526,360$ & $2,471,684$ & 1.646099866 & 1.610474636 \\
$35-39$ & $3,017,945$ & $2,944,616$ & 1.998252656 & 1.949699793 \\
$40-44$ & $3,269,926$ & $3,153,554$ & 2.201992613 & 2.123626838 \\
$45-49$ & $3,583,368$ & $3,399,267$ & 2.374450016 & 2.252459023 \\
\hline
\end{tabular}


Alive / Anak Lahir Hidup (ALH) according to the age group of women of childbearing age and Child's Still Alive / Anak Masih Hidup $(\mathrm{AMH})$ in the enumeration process. The IMR obtained from the SP2010 was analyzed using the Trussell method. It showed 24 deaths per 1,000 live births. It reduced from 2012 to 2016, and thus the result could be used as a reference.

Inputs of ALH and AMH from the previous Mortpak application were converted into Child Born Alive Rate (RALH) and Child's Still Alive Rate (RAMH) where each age group of ALH mothers was divided by the number of the female population in the same group.

$$
\begin{array}{ll}
R A L H= & \frac{A L H_{i}}{W U S_{i}} \\
R A M H= & \frac{A M H_{i}}{W U S_{i}} \\
\text { RALH } & =\text { Average ALH } \\
\text { RAMH } & =\text { Average AMH } \\
\mathrm{I} & =\text { Mother's age group }
\end{array}
$$

\section{Child Woman Ratio (CWR)}

Child Woman Ratio is the ratio of children to women of childbearing age. It was calculated by dividing the number of children aged 0-4 years by the number of the women population aged 15-49 years in East Java province.

$$
C W R=\frac{\text { Children }(0-4)}{W U S(15-49)} \times k
$$

$$
\begin{array}{ll}
\text { CWR } & =\text { Child Woman Ratio } \\
\text { WUS } & =\text { Women of Childbearing Age } \\
& \text { / Wanita Usia Subur } \\
k & =\text { Constant }(1,000 \text { inhabitants })
\end{array}
$$

Data on the number of children or population aged $0-4$ years were obtained from population data according to the 2015 Inter-census Population Survey age group, Central Bureau of Statistics East Java, which was $2,854,185$ and data on the number of female population 15-49 years. Details of the data can be seen in Table 2.

$$
\begin{aligned}
& C W R=\frac{2854185}{10404701} \times 1000 \\
& C W R=274,316
\end{aligned}
$$

Females in the age group of 15-49 years were used to meet the required data of fertile women (Wahyuni, 2012). The number of children under 5 years old was an indicator for calculating the TFR using the Palmore method.

$$
\begin{aligned}
& C P=\frac{\text { Number of } \text { children }_{0-4}}{\text { Total population }} \times 100 \% \\
& C P=\text { Child Percentage }
\end{aligned}
$$

The latest calculation of married women was done using the Palmore Formula A. The women involved were in the age group of 20-24 years and 15-49 years (Table 2). The Percentage of Ever Married (PEM) calculation formula is stated below. A summary on the calculations of the indicators is presented in Table 3.

$$
P E M=\frac{{\text { Married } \text { women }_{20-24 y r}}_{\text {wanita pernah kawin }} \text { ka }_{15-49 r}}{\times 100 \%}
$$

The child woman ratio (CWR) was obtained from the number of children 0-4 years old divided by the number of WUS 15-49 years old. This calculation was dependent on children born by the women of childbearing age. The percentage of married women aged 20-24 years was not much different from those aged 15-49 years. All of the calculations were calculated using the Palmore Formula A to find the TFR. The TFR in East Java Province was 2.01.

Table 2. Total Female Population in East Java Province in 2015

\begin{tabular}{ccc}
\hline $\begin{array}{c}\text { Age } \\
\text { (Years) }\end{array}$ & $\begin{array}{c}\text { Female } \\
\text { Residents }\end{array}$ & $\begin{array}{c}\text { Married } \\
\text { Women }\end{array}$ \\
\hline $15-19$ & $1,448,761$ & 169,728 \\
$20-24$ & $1,453,835$ & 814,232 \\
$25-29$ & $1,462,937$ & $1,280,648$ \\
$30-34$ & $1,534,755$ & $1,469,724$ \\
$35-39$ & $1,510,292$ & $1,469,860$ \\
$40-44$ & $1,484,985$ & $1,457,582$ \\
$45-49$ & $1,509,136$ & $1,484,731$ \\
\hline Total & $10,404,701$ & $8,146,505$ \\
\hline
\end{tabular}


Table 3. Calculation of the Palmore Formula A

\begin{tabular}{llll}
\hline \multicolumn{1}{c}{ Indicators } & \multicolumn{1}{c}{$\mathbf{X}$} & \multicolumn{1}{c}{ Y } & Results \\
\hline CWR $=$ & Number of children 0-4 years & $\begin{array}{l}\text { Total female resident aged } \\
15-49 \text { years }\end{array}$ & \\
X/Y.1000 & & $10,404,701$ & 274.316 \\
& $2,854,185$ & Total population & \\
\hline $\mathrm{CP}=$ & Number of children 0-4 years & & \\
$\mathrm{X} / \mathrm{Y} .100 \%$ & & $38,828,061$ & \\
& $2,854,185$ & Married women aged 15-49 & \\
\hline PEM $=$ & Married women aged 20-24 & years & 9.9948 \\
X/Y.100\% & years & $8,146,505$ & \\
& 814,232 &
\end{tabular}

The child woman ratio (CWR) was obtained from the number of children 0-4 years old divided by the number of WUS 15-49 years old. This calculation was dependent on children born by the women of childbearing age. The percentage of married women aged 2024 years was not much different from those aged 15-49 years. All of the calculations were calculated using the Palmore Formula A to find the TFR. The TFR in East Java province was 2.01 .

$$
\begin{gathered}
T F R=12.0405+13.5277(I M R) \\
+11.1042(C W R) \\
-176.4889(C P) \\
-6.4698(P E M) \\
T F R=12.0405+13.5277(23) \\
+11,1042(274.3168) \\
-176.4889(7.3508) \\
-6.4698(9.9948) \\
T F R=12,0405+312.057008+3046.0694 \\
-1297.34-64.6647 \\
=2008.1621 \\
T F R=\frac{2008.1621}{1000}=2.0081621
\end{gathered}
$$

\section{Comparison of Estimated TFR Using Palmore Formula A with National Figures}

The TFR using Palmore A formula generated the value of 2.01 which means that the woman mostly gave birth to two children.
The TFR from the 2010 data was 2.16. It showed a consistent decrease in the TFR. Fertility rates in the last five periods declined consistently as seen in SP1990, SUPAS 1995, SP2000, SUPAS 2005, and SP2010, respectively. A downward trend is shown in Figure 1.

Figure 1 explains there was a difference between TFR in 1990 and 1995, and so on. The difference between the periods showed ascending and descending patterns sequentially as the data each year had a different quality. Results of decreased rates can be seen in Table 4.

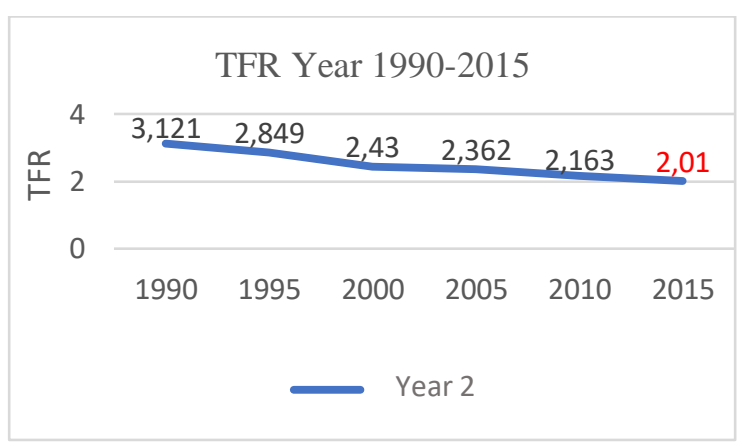

Figure 2. Fertility rates between 1990 and 2015.

A number marked red was the current finding as the Palmore Formula $\mathrm{A}$ was employed. It showed a steady decline but no sharp decline or increase.

Table 4. Fertility Rate in East Java in 1990-2010

\begin{tabular}{lccccc}
\hline \multicolumn{1}{c}{ Method } & $\mathbf{1 9 9 0}$ & $\mathbf{1 9 9 5}$ & $\mathbf{2 0 0 0}$ & $\mathbf{2 0 0 5}$ & $\mathbf{2 0 1 0}$ \\
& $\mathbf{( 1 9 8 7 )}$ & $\mathbf{( 1 9 9 2 )}$ & $(\mathbf{1 9 9 7 )}$ & $\mathbf{( 2 0 0 2 )}$ & $(\mathbf{2 0 0 7 )}$ \\
\hline Gunasekaran-Palmore & 3.861 & 2.840 & 2.450 & 2.230 & - \\
Palmore A & 3.121 & 2.849 & 2.430 & 2.362 & 2.163 \\
Own Children & 3.326 & 2.802 & 2.340 & 2.263 & 2.414 \\
Rele & 2.991 & 2.853 & 2.580 & 2.210 & 2.411 \\
\hline
\end{tabular}

Source: Demographic Parameter Estimation: Trends in Fertility, Mortality and Migration Results (SP2010) 


\section{DISCUSSION}

Infant Mortality Rate (IMR) commonly becomes an indicator to find out to which extent the government's program has been reinforced through health development programs. It also could determine the age group that has a higher risk of death in the future (Pramono, Wulansari, and Sutikno, 2013). The IMR in East Java province was quite good as observed in the SP2010 data life at the rate of 0.0250 for male and 0.020 for female below the national standard of 0.082 for male and 0.029 for female (Central Bureau of Statistics, 2015). According to the Indonesian Demographic and Health Survey, the IMR in East Java province from 2000-2010 continued to decline. Then in 2012, it increased to 30 per 1,000 live births. In 2015, it was at 24 per 1,000 infants born alive. That means during the periods, the IMR decreased.

Previous research stated from 19502000, several countries, including Indonesia, had tried to reduce fertility rates (Kusyanto, 2018). The decreased fertility rate in East Java province from 2005 to 2015 was slightly lower than the periods. It indicated that East Java province has achieved the national target of the TFR. The Indonesian Population Projections in 2010-2035 mentioned regions are likely to have Noise Reduction Rating (NRR) of 1. In other words, if the TFR is equal to 2.1, then the area likely will maintain its TFR with 1.2 children per woman as the limit (Central Bureau of Statistics, 2013). The Palmore Formula A can be used to calculate the next TFR. However, more qualified data sources are necessary to calculate TFR every period accurately.

\section{CONCLUSIONS AND SUGGESTIONS}

\section{Conclusion}

The total fertility rate (TFR) can be calculated through direct and indirect methods. It cannot be calculated directly because there are not enough data in several Indonesian regions. With this situation, the estimation calculation was done indirectly using the Palmore Formula A. The TFR was at 2.02, meaning that one mother gives birth to two children. The rate was then compared to SP1990, SUPAS 1995, SP2000, SUPAS 2005, and SP2010. The five data showed a decrease in trend but not significant. The Palmore Formula A is considered a good method in estimating fertility rates. Further research should use other estimation methods to find and compare the TFR in each region.

\section{Suggestion}

The current TFR calculations should not be used arbitrarily. There are many different estimation methods which require different data and produce different values in each period. The Palmore Formula A could be applied to various data sources to determine the consistent value. Besides, this formula could be replicated in other regions, not only in East Java, depending on the availability of the data.

\section{REFERENCES}

Central Bureau of Statistics, 2013. Proyeksi Penduduk Indonesia Indonesia Population Projection. [online] Jakarta: Central Bureau of Statistics. Available at: <https://www.bappenas.go.id/>.

Central Bureau of Statistics, 2015. Kajian lifetable indonesia. [online] Jakarta. Available $<$ https://www.bps.go.id/>.

Gunawan, G., Kurniati, E. and Sukarsih, I., 2017. Implementasi Model Perhitungan Perkiraan Total Fertility Rate (TFR) Berdasarkan Efektifitas Penggunaan Alat Kontrasepsi di Provinsi Jawa Barat. Matematika,16(2), pp.1-8.

Heryanah, 2015. Aging Population dan Bonus Demografi Kedua di Indonesia. Populasi, 23(2), pp.1-16.

Informer Technologies, I. (2020) 'Mortpak 4.3'. UN. Available at: $<$ https://mortpak.software.informer.co $\mathrm{m} />$.

Kusyanto, H., 2018. Review Penurunan Fertilitas di Negara Berkembang: Tren dan Penjelasan. Publikauma: Jurnal Administrasi Publik Universitas Medan Area, 5(2), p.34-40.

Marhaeni, A. and Rustariyuni, D., 2013. Studi Komparatif Fertilitas Penduduk Antara Migran dan Nonmigran di Provinsi Bali. Jurnal Kependudukan dan Pengembangan Sumber Daya Manusia, IX(2), pp.77-88.

Pramono, M., Wulansari, S. and Sutikno, S., 2013. Pemetaan Determinan Angka Kematian Bayi di Jawa Timur 
Berdasarkan Indikator Indeks Pembangunan Kesehatan Masyarakat. Buletin Penelitian Sistem Kesehatan, [online] 15(1 Jan), pp.38-46. Available at: <https://media.neliti.com/>.

Raharja, M.B., 2017. Fertilitas Menurut Etnis Di Indonesia: Analisis Data Sensus Penduduk 2010. Jurnal Kependudukan Indonesia, 12(1), pp.69-78.

Rahman, A., 2018. Menelusur Determinan Tingkat Fertilitas Jurnal EcceS Abstract: Tracking Determinants of Fertility Levels. Jurnal EcceS, 5(9), pp.57-77.

Ramadhani, A., Sumarno, H. and Mangku, I.W., 2017. Estimasi Fertilitas Dengan Model Coale-Trussell Dan Aplikasinya Terhadap Data Indone. Journal of Mathematics and Its Applications, 16(1), pp.1-12.

Rochaida, E., 2016. Dampak Pertumbuhan Penduduk Terhadap Pertumbuhan Ekonomi dan Keluarga Sejahtera di Provinsi Kalimantan Timur. Forum Ekonomi, 18(1), pp.14-24.

Samosir, OB and Rajagukguk, W., 2018. Demografi Formal. I ed. [online] Jakarta: UKI Press. Available at: <https://www.researchgate.net/publica tion/325795730>.
Salim, L., A, Lazuardi, L. and Kuntoro, K., 2018. Smart Fert: Aplikasi Praktis, Valid, dan Mudah Untuk Mengukur Indikator Fertilitas di Era Otonomi Daerah. Populasi, 25(1), pp.33-51.

Sorvianti, I., 2012. Pengukuran Fertilitas Menggunakan Metode Rele dan Gunasekaran-Palmore. [online] Institut Pertanian Bogor. Available at: <https://repository.ipb.ac.id/>.

Sudibia, I.K., Ayu, I.G., Dewi, M. and Rimbawan, I.N.D., 2015. Faktor-faktor yang Mempengaruhi Menurunnya Usia Kawin Pertama di Provinsi Bali. Piramida, 11(2), pp.43-58.

Syahbuddin, S. and Nurhayati, S., 2016. Determinan Fertilitas Di Indonesia (Determinant of Fertility in Indonesia). Kependudukan Indonesia, 11(1), pp.114.

Wahyuni, S. and Nuraini, 2012. Estimasi Parameter Demografi : Tren Fertilitas, Mortalitas dan Migrasi Hasil SP2010. [online] Jakarta: BPS. Available at: <https://www.bps.go.id/>. 